\title{
Evaluation of Strength Classes of Two Selected Less-used Nigerian Timber Species for Structural Applications
}

\author{
${ }^{1 *}$ Rahmon R. O., ${ }^{2}$ Oyeleke M. O. and ${ }^{1}$ Babatunde O. Y. \\ ${ }^{1}$ Department of Civil Engineering, University of Ilorin, Ilorin, Nigeria \\ ${ }^{2}$ Department of Civil Engineering, Federal Polytechnic Offa, Offa, Nigeria \\ *Corresponding author e-mail: rorahmon2222@gmail.com
}

\section{Abstract}

DOI:10.36108/laujoces/0202/40(0170)

As a result of increase in population growth and urbanization, the demand for timber in construction industry has exponentially increased. Common and popular timber in the industry do not meet up with the high demand and attention has been shifted to unpopular timber species such as Bush mango (Irvingia gabonensis) and Ire (Funtumia elastica) but their properties are yet to be fully researched and documented. This research therefore aimed at characterizing and grading of two less-used timber species in Kwara State, Nigeria for structural applications. The selected timber species were obtained from Irewolede Sawmill in Ilorin, Kwara State and various test specimens were prepared according to the BS 373: 1957 using Small Clear Size Specimens of Timber. A total of 200 specimens free from visible defects were used for the determination of the strength properties using the Universal Testing Machine of $300 \mathrm{kN}$ capacity at the Department of Agricultural and Biosystems Engineering, University of Ilorin in accordance with BS 373: 1957 (revised in 1999). It was revealed that Bush mango and Ire had average moisture contents of 13.95 and $12.71 \%$, respectively. For density classification, Bush mango and Ire were classified as medium and light wood, respectively. Bush mango and Ire were therefore graded according to NCP 2 (1973) and BS 5268 (2002) and assigned to their corresponding strength classes. Hence, Bush mango can be applied as bridge beam and railway sleepers while Ire can be used for lightweight furniture.

Keywords: Bush mango, Ire, Less-used, Strength classes, Timber species.

\section{Introduction}

Timber refers to wood in the form that is suitable for construction of carpentry, joinery or for reconversion for manufacturing purposes (Rahmon, et al., 2017). Timber is a structural material used for the construction of different types of structures and the major mechanical property considered in its selection is the strength (Rahmon, 2018). For timber members to be designed intelligently, the knowledge of the strength of timber under loads of different nature is important (Aguwa, 2010). The strength characteristics of timber depend on the species, density, moisture content, presence and type of wood defects as well as on the dimension of the structure (Aguwa, 2016; Ibitolu and Jimoh, 2017).

Nigeria is one of the countries that have timber in surplus quantity (Jimoh et al., 2017a). It is called the world's only renewable natural resource since a new one can be grown where one has been cut down. The world has just less than 4 billion hectares of forest which cover approximately $20 \%$ of the world's land area as reported by Obasi et al. (2015). Alamu, and Agbeja (2011) stated that forest reserves take possession of approximately 10 million hectares, standing for about $10 \%$ of a land area of approximately 96.2 million hectares in Nigeria. If this natural resource is properly utilized, it will be of immense benefit to the country in terms of reduction in the cost of construction (Aguwa, 2012; Rahmon, et al., 2017; Ibitolu and Jimoh, 2017). Different wood species have different strength characteristics, and also within a species, these characteristics may 
vary. Therefore, in practice, a classification system of strength classes is used (Jamala, et al., 2013; Jimoh et al., 2017b).

The need for local content in the construction of engineering infrastructure is now a serious engineering challenge in Nigeria. Due to vast quantities of local raw materials, which must be processed and used for cost-effective structures (Aguwa, 2016; Rahmon et al., 2017). Construction activities based on these locally available raw materials are major steps towards industrialization and economic independence for developing countries. This explains huge interest and considerable intellectual resources being invested in understanding the mechanical or structural properties of the Nigerian timber (Aguwa and Sadiku, 2011).

Fuwape (2000) reported that, if adequate information on the magnitude of the load, the rate of loading and the duration of load are provided, the appropriate timber species may be selected from the different timber strength groups and natural durability classes. The lack of sufficient information on some timbers has been the basis for their misuse and failure as a structural member. Information on the strength behaviour of these two less-used Nigerian timber species will help validate the structural viability of the species. Data of this type will serve as a guide for design and specification of these timbers for use as construction material. With adequate mechanical data on given specie of timber, loading information, the rate of loading and duration of loading can be so managed such that design of such timber will be adequate and safe use of such timber will be guaranteed. Hence, the need to study the mechanical properties of these timber species.

Irvingia gabonensis (Bush mango) is a species of African trees in the genus Irvingia, sometimes known by the common name wild mango, African mango, bush mango, dika or ogbono. They bear edible mango-like fruits and are especially valued for their fat-and protein-rich nuts. Irvingia gabonensis is indigenous to the humid forest zone from the northern tip of Angola, including Congo, DR Congo, Nigeria, Cote d'Ivoire and south-western Uganda. It is planted in parts of this area, such as in southeastern and south-western Nigeria and southern Cameroon. It grows straight, up to a height of $40 \mathrm{~m}$ and $1 \mathrm{~m}$ in diameter. It has buttresses to a height of $3 \mathrm{~m}$. The wood is hard and therefore used for heavy construction work as making ships decks or railway ties. Dead branches are used as firewood (Rahmon, 2018).

Funtumia elastica (Ire) is a tree of height up to $30 \mathrm{~m}$, with not quite straight, cylindrical, unbuttressed bole, $2.50 \mathrm{~m}$ in girth, of the deciduous forest from Guinea to West Cameroons and in the Congo basin, and along the Nile basin in Egypt, Sudan, and Uganda. It belongs to the family Apocynaceae. The wood is white and soft, and undifferentiated between sap and heart. Though it was traded under the name of 'Lagos rubber' and the Yoruba name 'Ire' and variations, the tree appears to have been first exploited to a limited extent in Cameroon (Jimoh and Rahmon, 2018). Strength classification of timber species offers a number of advantages both to the designer and the supplier of timber. The designer can undertake his design without the need to check on the availability and price of a large number of species and grades which he might use. Suppliers can supply any of the species/grade combinations that meet the strength class in a specification. The concept also allows new species to be introduced onto the market without affecting existing specifications for timber. The assignment of timber species to a strength class allows engineers to use the mechanical properties of the strength class in limit state design of timber structures. Material properties for grading include density, bending modulus of elasticity and bending 
strength that is obtained from laboratory experiments. In this research, the grading of timber species was in accordance with BS 5268: 2002 and NCP 2: 1973.

The determined properties such as density, grade bending stress and mean modulus of elasticity were used for grading and assigning strength class according to the national and international code of practice (NCP 2: 1973; BS 5268 part 2: 2002). The aim of this study was to characterize and grade Nigeria grown Irvingia gabonensis (Bush mango) and Funtumia elastica (Ire) timber species in accordance with BS 5268 (2002) and NCP 2 (1973). The specific objectives were to obtain, season, prepare samples of Irvingia gabonensis and Funtumia elastica, determine their physical and mechanical properties according to BS 373 (1957) and to grade Irvingia gabonensis and Funtumia elastica timber specie in accordance with BS 5268 (2002) and NCP 2 (1973).

\section{Materials and methods}

Timber materials used in this study were obtained from matured Irvingia gabonensis and Funtumia elastica trees in green condition from Irewolede Sawmills, Ilorin, Kwara State and sawn to size $100 \times 150 \times 3600 \mathrm{~mm}$. Five logs of timber free from visible defects were selected and they were reduced to $100 \times 150 \times 1800 \mathrm{~mm}$ for easy transportation to the Wood section of the Department of Civil Engineering Laboratory, Faculty of Engineering and Technology, University of Ilorin, Ilorin, Nigeria for seasoning, preparation, and physical testing.

\section{Preparation of test specimens}

Test specimens were seasoned for six months to attain equilibrium moisture condition (EMC) at Wood section of Department of Civil Engineering Laboratory, University of Ilorin, Nigeria. Natural seasoning method was adopted in line with Aguwa (2010). Twenty (20) samples were prepared for different laboratory tests which include three-point bending strength parallel to the grain, shear strength parallel to the grain, tension strength parallel to the grain, compressive strength parallel to the grain, compressive strength perpendicular to the grain, natural moisture content, specific gravity, and density according to BS 373 (1957).

Determination of physical and mechanical properties: Physical and mechanical/strength properties for the various mechanical tests were determined using the prepared samples at the Department of Agricultural and Biosystems Engineering Laboratory, Faculty of Engineering and Technology, University of Ilorin, Ilorin using Universal Testing Machine (UTM), Testometric Model of $300 \mathrm{kN}$ capacity with computer interface for data acquisition and analysis. Tests carried out to include three-point bending strength parallel to the grain, shear strength parallel to the grain, tension strength parallel to the grain, compressive strength parallel to the grain, compressive strength perpendicular to the grain, natural moisture content, and density according to BS 373 (1957). In each set of the tests, failure loads were recorded for computation of failure stresses, mean failure stress, standard deviation and coefficient of variation.

Stresses at $12 \%$ and $18 \%$ moisture content: Failure stresses for bending parallel to the grain, tension parallel to the grain, compression parallel to the grain, compression perpendicular to the grain and shear parallel to the grain were adjusted to values at $12 \%$ and $18 \%$ moisture content in accordance with BS 5268 (2002) and NCP 2 (1973). Equation (1) and (2) were used for the adjustment.

$$
F_{12}=F_{w}(1+\alpha(W-12))
$$




$$
F_{18}=F_{w}(1+\alpha(W-18))
$$

Where:

$\mathrm{F}_{12}=$ failure stress at $12 \%$ moisture content,

$\mathrm{F}_{18}=$ failure stress at $18 \%$ moisture content

$\mathrm{W}=$ experimental moisture content in $(\%)$,

$\mathrm{F}_{\mathrm{w}}=$ experimental failure stress,

$\alpha=$ correction factor (Bending $=0.04$, compression $=0.05$, shear $=0.03$, tension $=0.05$ and $\mathrm{MOE}=0.02)($ Rahmon, 2018).

\section{Modulus of elasticity}

Based on three points bending test, Equation (3) from the strength of materials applied to straight beams was used, in conformity with Aguwa et al. (2015).

$$
E_{L 3}=\frac{l^{3}}{4 e h^{3}} k
$$

where, $\mathrm{EL}_{3}$ is the three-point bending modulus of elasticity, $\ell$ is the distance between the two supports $(280 \mathrm{~mm})$, e is the width of the beam $(20 \mathrm{~mm}), \mathrm{h}$ is the height of the beam $(20 \mathrm{~mm})$ and $\mathrm{k}$ is the slope of load-deformation graph that is. Minimum modulus of elasticity was determined by Equation (4) which shows the relationship between mean modulus of elasticity, Emean and the minimum modulus of elasticity, $\mathrm{E}_{\min }$.

$$
E_{\text {min }}=E_{\text {mean }}-\frac{2.33 \sigma}{\sqrt{N}}
$$

where $\mathrm{N}$ is the number of specimens, is the standard deviation

\section{Modulus of elasticity at $12 \%$ and $18 \%$ moisture content}

Moduli of elasticity at experimental moisture content was adjusted to values at $12 \%$ and $18 \%$ moisture content in conformity with BS 5268 (2002) and NCP 2 (1973). The adjusted values were computed with Equation (5) and (6).

$$
\begin{aligned}
& E_{m 12}=\frac{E_{\text {measured }}}{1+0.0143(12-u)} \\
& E_{m 18}=\frac{E_{\text {measured }}}{1+0.0143(18-u)}
\end{aligned}
$$

where $\mathrm{E}$ measured $=$ the modulus of elasticity at experimental moisture content, $\mathrm{E}_{\mathrm{m} 12}=$ Modulus of elasticity at $12 \%$ moisture content, $\mathrm{E}_{\mathrm{m} 18}=$ Modulus of elasticity at $18 \%$ moisture content and $\mathrm{U}=$ experimental moisture content. 


\section{Determination of moisture content}

Samples of size $20 \times 20 \times 40 \mathrm{~mm}$ were cut from the seasoned timber and used for the determination of the moisture content in accordance with BS 373 (1957). The oven temperature was maintained constantly at $103 \pm 2^{\circ} \mathrm{C}$ for several hours until a stable mass was obtained. Equation (7) was used for the calculation of moisture content.

$$
M C=\frac{m_{1}-m_{2}}{m_{2}} \times 100 \%
$$

where $M C=$ moisture content, $\mathrm{m}_{1}=$ Initial mass of timber before oven dried, $\mathrm{m}_{2}=$ final mass of timber after oven drying.

\section{Determination of Density}

Five samples of the timber with size $20 \times 20 \times 20 \mathrm{~mm}$ were used for the determination of the density in accordance with BS 373 (1957). Density was calculated using Equation (8).

$$
\rho=\frac{m}{v}
$$

where, $\rho=$ density of the timber specimen, $\mathrm{m}=$ the mass of the timber specimen, and $\mathrm{v}=$ volume of the timber specimen.

Density at $12 \%$ and $18 \%$ moisture content: The densities computed from test results in $\mathrm{kg} / \mathrm{m}^{3}$ were adjusted to values at $12 \%$ and $18 \%$ moisture content in accordance with BS 5268 (2002) and NCP 2 (1973). Equation (9) and (10) was used for the adjustment.

$$
\begin{aligned}
& \rho_{12}=\rho_{w}\left[1-\frac{(1-0.5)(u-12)}{100}\right] \\
& \rho_{18}=\rho_{w}\left[1-\frac{(1-0.5)(u-18)}{100}\right]
\end{aligned}
$$

where is $\rho_{12}=$ density at $12 \%$ moisture content in $\mathrm{kg} / \mathrm{m}^{3}, \rho_{12}=$ density at $12 \%$ moisture content in $\mathrm{kg} / \mathrm{m}^{3}, \rho_{\mathrm{w}}=$ density at experimental moisture content, $u=$ experimental moisture content in $\%$.

\section{Basic and grade stresses}

Basic stresses for bending, tensile, compressive, shear parallel to the grain, compressive stress perpendicular to the grain, were calculated from failure stresses. Equation (11) was used for the computation. Various grade stresses at $80,63,50$ and $40 \%$ values, respectively were calculated according to BS 5268 (2002).

$$
f_{b}=\frac{f_{m}-k_{p} \sigma}{k_{r}}
$$

where $\mathrm{f}_{\mathrm{b}}=$ basic stress, mean failure stress at $12 \%$ moisture content, $\sigma=$ standard deviation of failure stress, $\mathrm{k}_{\mathrm{r}}=$ reduction factor and $\mathrm{k}_{\mathrm{p}}=$ modification factor $=2.33, \mathrm{~K}_{\mathrm{r}}$ for bending, tension 
and shear parallel to the grain $=2.25 . \mathrm{K}_{\mathrm{r}}$ for compression parallel to the grain $=1.4$ while $\mathrm{K}_{\mathrm{r}}$ for compression perpendicular to the grain =1.2 (Aguwa et al., 2015; Ozelton and Baird, 1981).

\section{Test specimen arrangements}

Figures 1-4 show the test specimen arrangement for various mechanical/strength tests carried on the timber species using Testometric Universal Testing Machine (UTM) of capacity $300 \mathrm{kN}$ at the Agricultural and Biosystems Engineering Laboratory, Faculty of Engineering and Technology, University of Ilorin, Ilorin, Ilorin, Nigeria.

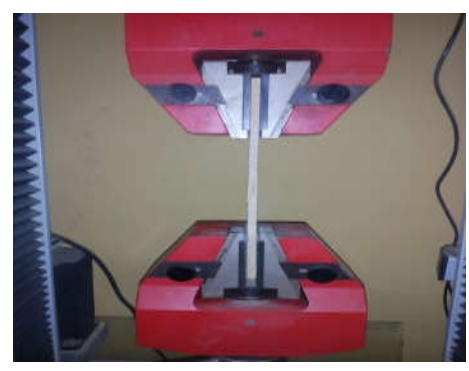

Figure 1: Tension Test arrangement

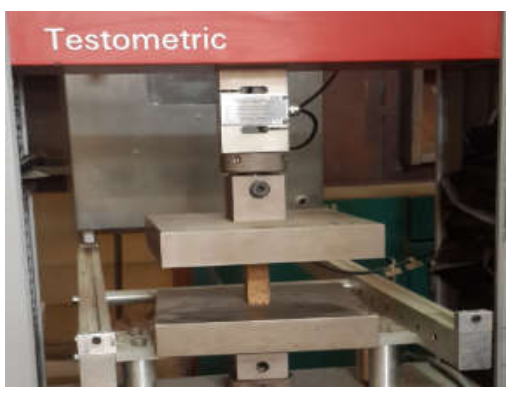

Figure 2: Compression Test arrangement

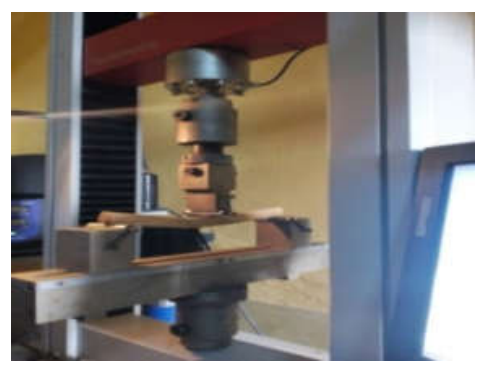

Figure 3: Bending Test arrangement 


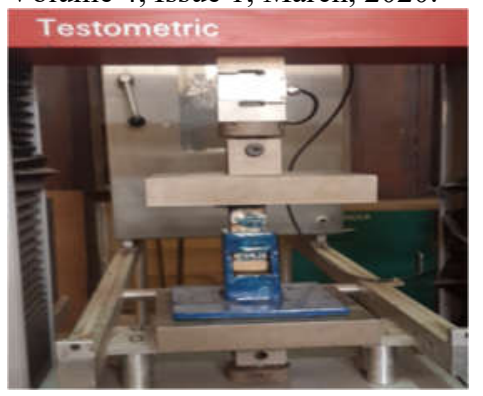

Figure 4: Shear Test arrangement

\section{Results and Discussion \\ Physical properties}

Tables $1 \mathrm{a}$ and $1 \mathrm{~b}$ show the results obtained from the laboratory experiments carried out for the physical properties of the timber species under consideration. The Physical and mechanical properties of the timber species tested are presented in Table 1. It was revealed that the density obtained for Bush mango and Ire were 714.50 and $389.13 \mathrm{~kg} / \mathrm{m}^{3}$, respectively which implies that the timber species investigated, that is Bush mango and Ire were hardwood and softwood according to Nigeria Code of Practice, NCP 2 (1973) classification. Also, moisture content results show that the values obtained which are 13.95 and $12.71 \%$ for Bush mango and Ire, respectively were below Fibre Saturation Point (FSP) that is, below $25 \%$ moisture content as stated by Nabade (2012).

Table 1a: Density of the timber species

\begin{tabular}{|c|c|c|c|c|c|c|c|}
\hline \multirow{3}{*}{$\begin{array}{l}\text { Timber } \\
\text { species }\end{array}$} & \multicolumn{7}{|c|}{ Density $\left(\mathrm{kg} / \mathrm{m}^{3}\right)$} \\
\hline & \multirow[t]{2}{*}{ Min. } & \multirow[t]{2}{*}{ Max. } & \multirow[t]{2}{*}{ Mean } & \multirow{2}{*}{$\begin{array}{l}\text { Std. } \\
\text { Dev. }\end{array}$} & \multirow{2}{*}{$\begin{array}{c}\text { Coef. } \\
\text { of } \\
\text { Var. }\end{array}$} & \multicolumn{2}{|c|}{ Confidence Limit } \\
\hline & & & & & & $95 \%$ & $99 \%$ \\
\hline $\begin{array}{l}\text { Bush } \\
\text { mango }\end{array}$ & 686.74 & 734.23 & 714.50 & 10.82 & 1.51 & $710.26 \leq x \leq 718.74$ & $708.93 \leq x \leq 720.07$ \\
\hline Ire & 321.28 & 463.36 & 389.13 & 25.96 & 6.67 & $378.95 \leq x \leq 399.31$ & $375.76 \leq x \leq 402.50$ \\
\hline
\end{tabular}

Table 1b: Moisture content of the timber species

\begin{tabular}{|c|c|c|c|c|c|c|c|}
\hline \multirow{3}{*}{ Timber } & \multicolumn{7}{|c|}{ Moisture content $(\%)$} \\
\hline & \multirow[t]{2}{*}{ Min. } & \multirow[t]{2}{*}{ Max. } & \multirow[t]{2}{*}{ Mean } & \multirow{2}{*}{$\begin{array}{l}\text { Std. } \\
\text { Dev. }\end{array}$} & \multirow{2}{*}{$\begin{array}{l}\text { Coef. } \\
\text { of } \\
\text { Var. }\end{array}$} & \multicolumn{2}{|c|}{ Confidence Limit } \\
\hline & & & & & & $95 \%$ & $99 \%$ \\
\hline $\begin{array}{l}\text { Bush } \\
\text { mango }\end{array}$ & 10.85 & 17.16 & 13.95 & 1.43 & 10.28 & $13.39 \leq \mathrm{x} \leq 14.51$ & $13.21 \leq \mathrm{x} \leq 14.69$ \\
\hline Ire & 9.67 & 16.23 & 12.71 & 1.73 & 13.64 & $12.03 \leq x \leq 13.39$ & $11.82 \leq x \leq 13.60$ \\
\hline
\end{tabular}

\section{Mechanical properties}

Tension parallel to grain: The mean values for tension parallel to grain strength of the species at $12 \%$ moisture content are presented in Table 2. It was observed that Bush mango, recorded higher mean Tension parallel to grain which was $62.39 \mathrm{~N} / \mathrm{mm}^{2}$ (that is, it has higher resistance to failure in Tension parallel to grain than Ire at the same moisture content.) while Ire gave the lower 
Tension parallel to grain strength value which was $59.20 \mathrm{~N} / \mathrm{mm}^{2}$. When compared tension parallel to grain results to some known species, Emi-gbegi, $45.37 \mathrm{~N} / \mathrm{mm}^{2}$ (Ibitolu and Jimoh, 2017), Prosopis Africana, 13.6N $/ \mathrm{mm}^{2}$ (Ataguba et al., 2015), Adeyemi, (2016) recorded $77.69 \mathrm{~N} / \mathrm{mm}^{2}$ for Ara and Adefemi, (2015) recorded $69.61 \mathrm{~N} / \mathrm{mm}^{2}$ for Apa. The values obtained for Bush mango and Ire were found to be satisfactory, since the determined values from test are within the ranges.

Table 2: Result of tension parallel to grain strength of the species

\begin{tabular}{lcc}
\hline & Bush mango & Ire \\
\hline Mean failure stress (N/mm $)$ & 56.85 & 57.17 \\
Standard deviation & 6.86 & 6.25 \\
Moisture content (\%) & 14.21 & 13.69 \\
Strength @ 12\% MC & 62.39 & 59.20 \\
Strength @ 18\% MC & 45.34 & 42.05 \\
Basic stress (N/mm $\left.{ }^{2}\right)$ & 18.16 & 18.94 \\
$80 \%$ Grade stress $\left(\mathrm{N} / \mathrm{mm}^{2}\right)$ & 14.53 & 15.15 \\
\hline
\end{tabular}

Compression perpendicular to grain: The results of compression perpendicular to grain for the timber species are shown in Table 3. The results indicated that Bush mango recorded higher mean compression perpendicular to grain which was $50.16 \mathrm{~N} / \mathrm{mm}^{2}$ while Ire gave the lower value of $37.11 \mathrm{~N} / \mathrm{mm}^{2}$. This implies that the resistance of Bush mango to failure in compression perpendicular to grain was higher than the other specie at the same moisture content. By comparing the observed values for the Bush mango and Ire with the already established values such as Neem: $30.35 \mathrm{~N} / \mathrm{mm}^{2}$ (Aina, 2016), Adere: $8.60 \mathrm{~N} / \mathrm{mm}^{2}$, Eriri: $10.60 \mathrm{~N} / \mathrm{mm}^{2}$, and Emigbegi: $12.20 \mathrm{~N} / \mathrm{mm}^{2}$ (Ibitolu and Jimoh, 2017), Iponhon: $21.61 \mathrm{~N} / \mathrm{mm}^{2}$ (Adeyemi, 2016). The value for Bush mango and Ire were found to be higher than the reported values but are in line with the values reported in Aguwa (2016).

Table 3. Result of compressive strength perpendicular to grain of the species

\begin{tabular}{lcc}
\hline & Bush mango & Ire \\
\hline Mean failure stress (N/mm $)$ & 45.70 & 35.84 \\
Standard deviation & 13.10 & 8.42 \\
Moisture content (\%) & 14.52 & 12.69 \\
strength @ 12\% MC & 50.16 & 37.11 \\
strength @ 18\% MC & 36.45 & 26.36 \\
Basic stress (N/mm $)$ & 16.69 & 16.11 \\
$80 \%$ Grade stress $\left(\mathrm{N} / \mathrm{mm}^{2}\right)$ & 13.35 & 12.89 \\
\hline
\end{tabular}

Compression parallel to grain: Table 4 presented the results of the mean compression parallel to grain strength for Bush mango and Ire. It can be observed that the value obtained for Bush mango was greater than that of Ire, that is, $71.97 \mathrm{~N} / \mathrm{mm}^{2}>20.01 \mathrm{~N} / \mathrm{mm}^{2}$. This means that the resistance of Bush mango to failure in compression parallel to grain was higher than that of Ire timber species at the same moisture content. While comparing the values obtained with some already established results such as Apa: $28.59 \mathrm{~N} / \mathrm{mm}^{2}$ (Adefemi, 2015) and Khaya senegalensis, 54N/mm ${ }^{2}$ (CIRAD, 2009), the results were found to be within the range. 
Table 4: Result of compression parallel to grain strength of the species

\begin{tabular}{lcc}
\hline & Bush mango & Ire \\
\hline Mean failure stress $\left(\mathrm{N} / \mathrm{mm}^{2}\right)$ & 65.58 & 19.32 \\
Standard deviation & 5.68 & 1.82 \\
Moisture content (\%) & 13.69 & 11.99 \\
strength @ 12\% MC & 71.97 & 20.01 \\
strength @ 18\% MC & 52.30 & 14.21 \\
Basic stress (N/mm $\left.{ }^{2}\right)$ & 37.39 & 10.77 \\
$80 \%$ Grade stress $\left(\mathrm{N} / \mathrm{mm}^{2}\right)$ & 29.91 & 8.62 \\
\hline
\end{tabular}

Shear parallel to grain test: The values of shear parallel to grain test for the timber species are presented in Table 5. Bush mango recorded highest mean shear parallel to grain which was $4.48 \mathrm{~N} / \mathrm{mm}^{2}$ while Ire gave a mean value of $3.69 \mathrm{~N} / \mathrm{mm}^{2}$. It is observed from the results that, the resistance of Bush mango to failure in shear parallel to grain was higher than that of the other specie at the same moisture content. When compared the shear parallel to grain results to some known species, Neem has $7.40 \mathrm{~N} / \mathrm{mm}^{2}$ (Aina, 2016) and Xylopia aethiopica $14.04 \mathrm{~N} / \mathrm{mm}^{2}$ (Jimoh and Aina, 2017).

Table 5: Result of shear parallel to grain strength of the species

\begin{tabular}{|c|c|c|}
\hline & Bush mango & Ire \\
\hline Mean failure stress $\left(\mathrm{N} / \mathrm{mm}^{2}\right)$ & 4.23 & 3.61 \\
\hline Standard deviation & 1.16 & 0.89 \\
\hline Moisture content $(\%)$ & 14.57 & 13.69 \\
\hline Strength@12\% MC & 4.48 & 3.69 \\
\hline Strength@18\% MC & 3.72 & 3.04 \\
\hline Basic stress $\left(\mathrm{N} / \mathrm{mm}^{2}\right)$ & 0.68 & 0.68 \\
\hline $80 \%$ Grade stress $\left(\mathrm{N} / \mathrm{mm}^{2}\right)$ & 0.54 & 0.55 \\
\hline
\end{tabular}

Modulus of elasticity (MOE): Modulus of Elasticity (MOE) is a measure of resistance to bending and is calculated by formula $\mathrm{PL}^{3} / 4 \mathrm{bd}^{3}$ (method A) of BS 373: 1957. This is the amount of deflection of timber in response to a load. The Modulus of elasticity strength values of the two species at $12 \%$ moisture content are shown in Table 6 . Bush mango timber showed higher strength values than resistance to bending than the other species. The overall order of decreasing MOE of the species was as follows: Bush mango > Ire. When compared to known species, such as The $12 \%$ moisture content of Eku timber specie was found to be higher than $5500 \mathrm{~N} / \mathrm{mm}^{2}$ for Obeche, (Aina, 2016), Adeyemi, (2016) obtained at $12 \%$ moisture content a value of $5525.28 \mathrm{~N} / \mathrm{mm}^{2}$ for Omo, Khaya ivorensis $\left(8192.54 \mathrm{~N} / \mathrm{mm}^{2}\right)$ by Jamala et al. (2013). The value for Khaya ivorensis is higher than that of Ire, whereas the value obtained for Obeche, Omo and Khaya ivorensis are all less than the value obtained for Bush mango. 
Table 6: Result of modulus of elasticity of the species

\begin{tabular}{|c|c|c|}
\hline & Bush Mango & Ire \\
\hline Mean failure stress $\left(\mathrm{N} / \mathrm{mm}^{2}\right)$ & 20573.88 & 7430.90 \\
\hline Standard deviation & 1048.38 & 1145.40 \\
\hline Moisture content (\%) & 12.73 & 11.82 \\
\hline Strength@12\% MC & 21376.26 & 7536.42 \\
\hline Strength@18\% MC & 18907.40 & 6644.71 \\
\hline Basic stress $\left(\mathrm{N} / \mathrm{mm}^{2}\right)$ & 8058.29 & 2116.50 \\
\hline $80 \%$ Grade stress $\left(\mathrm{N} / \mathrm{mm}^{2}\right)$ & 6446.63 & 1693.20 \\
\hline
\end{tabular}

Modulus of rupture (MOR): From Table 7, at 12\% moisture content, the average modulus of rupture of Bush mango was $190.40 \mathrm{~N} / \mathrm{mm}^{2}$ while Ire has the lower value of $60.33 \mathrm{~N} / \mathrm{mm}^{2}$. It is therefore obtained from the result that the resistance of Bush mango to static bending (MOR) was higher than that of the other specie at the same moisture content. When compared with $50.13 \mathrm{~N} / \mathrm{mm}^{2}$ recorded for Black Afara (Kaura et al., 2015) and $90.41 \mathrm{~N} / \mathrm{mm}^{2}$ for Meliceae exclesa (Jamala et al., 2013), D. fusca, 65.14N/mm $\mathrm{m}^{2}$ and D. rappa, $61.32 \mathrm{~N} / \mathrm{mm}^{2}$ (Duju and Hisham, 2015), Ahun, 39.36N/mm² (Mohammed, 2014).

Table 7: Result of modulus of rupture of the species

\begin{tabular}{lcc}
\hline & Bush mango & Ire \\
\hline Mean failure stress $\left(\mathrm{N} / \mathrm{mm}^{2}\right)$ & 176.62 & 58.66 \\
Standard deviation & 16.18 & 6.46 \\
Moisture content (\%) & 12.13 & 11.69 \\
Strength @ 12\% MC & 190.40 & 60.33 \\
Strength @ 18\% MC & 148.01 & 46.25 \\
Basic stress (N/mm $\left.{ }^{2}\right)$ & 61.74 & 19.38 \\
$80 \%$ Grade stress $\left(\mathrm{N} / \mathrm{mm}^{2}\right)$ & 49.39 & 15.51 \\
\hline
\end{tabular}

Regarding wood mechanical properties, the arrangement and proportions of ground tissues (axial and ray parenchyma, fibres and vessels) in hardwood species are considered to play a key role (Bowyer et al., 2003). From Table 8, it can be concluded that at 12\% moisture content, the mechanical properties of the species vary from one another, this can be associated with a considerable difference in density between the species. Also from the Table, Bush mango has highest modulus of rupture, modulus of elasticity and compression perpendicular to grain strength.

Table 8: Principal mechanical properties of the timber species at $12 \%$ moisture content

\begin{tabular}{lcc}
\hline Mechanical properties & Bush mango & Ire \\
\hline MOE $\left[\mathrm{N} / \mathrm{mm}^{2}\right]$ & 21376.26 & 7536.42 \\
MOR $\left[\mathrm{N} / \mathrm{mm}^{2}\right]$ & 190.40 & 60.33 \\
Compression // to grain $\left[\mathrm{N} / \mathrm{mm}^{2}\right]$ & 71.97 & 20.01 \\
Compression $\perp$ to grain $\left[\mathrm{N} / \mathrm{mm}^{2}\right]$ & 50.16 & 37.11 \\
Tensile strength $\left[\mathrm{N} / \mathrm{mm}^{2}\right]$ & 62.39 & 59.20 \\
Shear parallel to grain $\left[\mathrm{N} / \mathrm{mm}^{2}\right]$ & 4.48 & 3.69 \\
\hline
\end{tabular}


Strength classification: According to NCP 2:1973, the 80\% Grade stresses of the two Nigerian timber species are given in Table 9, using the Bending parallel to grain strength values. Comparing these values with Table 7 of NCP 2:1973 Dry Grade stresses of Timbers, the following strength groups were obtained. This shows that Bush mango is stronger than Ire timber species. The strength classes for Nigerian timber species in general range from the highest grade N1 to the weakest grade N7 strength classes. Grade stresses obtained for Bush mango and Ire timber species in modulus of rupture, had been allocated to strength class N1 and N5 which implies that Bush mango is suitable for use in load bearing structures such whereas Ire species is suitable for use in furniture components, plywood and joineries.

Table 9: Strength class allocation (NCP 2:1973)

\begin{tabular}{lccc}
\hline Timber species & $\begin{array}{c}\text { Experimental Stresses } \\
\left(\mathrm{N} / \mathrm{mm}^{2}\right)\end{array}$ & $\begin{array}{c}\text { NCP 2 80\% Grade } \\
\left.\text { Stresses (N/mm }{ }^{2}\right)\end{array}$ & $\begin{array}{c}\text { Strength } \\
\text { Classes }\end{array}$ \\
\hline Bush mango (Irvingia & 176.62 & 49.39 & $\mathrm{~N} 1$ \\
gabonensis) & 58.66 & 15.51 & $\mathrm{~N} 5$ \\
Ire (Funtumia elastica) & & & \\
\hline
\end{tabular}

According to BS 5268 (2002), strength class may be assigned to a specie, if its characteristic value of grade bending stress and mean density equal or exceed the value for that class giving in Table 8 of BS 5268-2 (2002) and its mean modulus of elasticity in bending equal or exceed $95 \%$ of the value given in that strength class. Based on these criteria, Bush mango and Ire were assigned to strength class D70 and C14 respectively due to their material properties such as grade bending stress parallel to the grain, mean density as well as mean modulus of elasticity as specified by the code. Table 10 shows the strength allocation according to BS 5268 (2002).

Table 10: Material properties for BS 5268 classification

\begin{tabular}{lcccc}
\hline Timber species & $\begin{array}{c}\text { Grade stress } 80 \\
\left(\mathrm{~N} / \mathrm{mm}^{2}\right)\end{array}$ & $\begin{array}{c}\text { Mean Modulus of } \\
\text { Elasticity }\left(\mathrm{N} / \mathrm{mm}^{2}\right)\end{array}$ & $\begin{array}{c}\text { Density } \\
\left(\mathrm{kg} / \mathrm{m}^{3}\right)\end{array}$ & Strength Classes \\
\hline Bush mango & 49.39 & 20573.88 & 714.50 & $\mathrm{D} 70$ \\
Ire & 15.51 & 7430.90 & 389.13 & $\mathrm{C} 14$ \\
\hline
\end{tabular}

\section{Conclusions}

Laboratory experiments were conducted to determine the physical and mechanical properties of two (2) less-used Nigerian timber species, namely: Bush mango (Irvingia gabonensis), and Ire (Funtumia elastica), in accordance with BS 373: 1957. The density classification of the timber species according to Findlay (1975) are as follows: heavy/medium wood for Bush mango and light wood for Ire. The mean values of MC with respect to all the two timber species, that is 13.95 and $12.71 \%$ for Bush mango and Ire, respectively were found to fall below the fibre saturation point (FSP) which is usually between $25-30 \% \mathrm{MC}$ according to Nabade (2012). From the results, the physical and structural (strength properties) were established. The two (2) timber species were successfully characterized and graded accordingly. Bush mango and Ire timber species were, therefore graded according to NCP 2 (1973) and assigned to their corresponding strength classes as N1 and N7, respectively. However, in accordance to BS 5268 (2002), Bush mango and Ire were assigned to strength classes D70 and C14, respectively. Hence, the two timber species were successfully characterized and graded. The results were also compared with other commonly used 
species. The results of this work will help Structural Engineers to design and construct timber structures using locally available timber instead of foreign ones. More research should be carried out on ways in which timber can be improved for construction purposes, development of software tools for timber building professionals.

\section{References}

Adefemi, J.B. (2015). Characterisation of Apa (Afzelia bipindensis) timber grown in Kwara state of Nigeria for Structural use, Unpublished M.Eng. Thesis, submitted to the Department of Civil Engineering, University of Ilorin, Ilorin, Nigeria.

Adeyemi, F.O. (2016). Characterization and Grading of some selected Nigerian Timbers Grown in Kwara State for Structural use, Unpublished M.Eng Thesis, submitted to the Department of Civil Engineering, University of Ilorin, Ilorin, Nigeria.

Aguwa, J.I. (2010). Reliability studies on the Nigerian timber as an orthotropic structural material, PhD Thesis submitted to the Department Civil Engineering, Federal University of Technology, Minna, Nigeria.

Aguwa, J.I. (2012). Reliability assessment of the Nigeria Apa (Afzelia bipindensis) timber bridge beam subjected to bending and deflection under limit state of loading, International Journal of Engineering and Technology, 2(6): 1076-1087.

Aguwa, J.I. (2016). The Nigerian Timber Structures, Ahmadu Bello University press Limited, P.M.B. 1094, Samaru, Zaria, Nigeria.

Aguwa, J.I., Chukwu, P.C. and Auta, S. (2015). Characterization and Grading of South Eastern Nigeria grown Irvingia gabonensis Timber in accordance with BS 5268, USEP: Journal of Research Information in Civil Engineering, 12(2): 720-731.

Aguwa, J.I. and Sadiku, S. (2011). Structural Reliability Analysis on the Nigeria Ekki timber bridge beam subjected to shearing force under Ultimate limit state, Research Journal in Engineering and Applied Sciences, 1(4): 240-246.

Aina, S. (2016). Characterization of Neem tree (Azadirachta indica) grown in Kwara State, Nigeria for Structural Use, Unpublished M.Eng. Thesis submitted to the Department of Civil Engineering, University of Ilorin, Ilorin, Nigeria.

Alamu, L.O and Agbeja, B.O. (2011). Deforestation and endangered indigenous tree species in South-West Nigeria, International Journal of Biodiversity and Conservation (Ed.). Academic Journals, 3(7): 291 - 297.

Ataguba, C., Enwelu, C., Aderibigbe, W. and Okiwe, E. 2015. A Comparative Study of Some Mechanical Properties of Gmelina Arborea, Parkia Biglobosa and Prosopis Africana Timbers for Structural Use, International Journal of Technical Research and Applications, 3(3): 320-324.

British Standards, BS 373 (1957). Method of Testing Small Clear Specimens of Timber, British Standard Institute, London.

British Standards, BS 5268 (2002). Structural Use of Timber. Part 2: Code of Practice for Permissible Stress Design, Materials, and Workmanship. British Standard Institute, London.

Bowyer, L.J., Shmulsky, R, and Haygreen, G.J. (2003). Forest Products and Wood Science: An Introduction, 4th Edition. Blackwell Publishing Company, Iowa.

Findlay, W.P.K. (1975). Timber Properties and Uses. Forest Product Research Laboratory, Granada Publishing by Crosby Lockwood Staples, London, Toronto, Sydney, New-York, United State of America. pp. 1-589.

Fuwape, J.A. (2000). Wood Utilization: From Cradle to the Grave, 25th Inaugural Lecture of the Federal University of Technology, Akure. http://www.nuc.edu.ng.

Ibitolu, B.J. and Jimoh, A.A. (2017). Characterization and Grading of some Potential Nigerian Timber Species in accordance with Eurocode EN 338 (2009). 2nd International Engineering Conference (IEC 2017). Federal University of Technology, Minna, Nigeria, pp. 433-440. 
Jamala, G.Y., Olubunmi, S.O., Mada, D.A. and Abraham, P. (2013). Physical and Mechanical Properties of Selected Wood Species in Tropical Rainforest Ecosystem, Ondo State, Nigeria, IOSR Journal of Agriculture and Veterinary Science (IOSR-JAVS), 5(3): 29-33.

Jimoh, A.A. and Rahmon, R.O. (2018). Mechanical Characterization and Grading of Irvingia gabonensis timber specie according to British and Nigerian Standards from Kwara State, Nigeria, ANNALS of Faculty of Engineering, Hunedoara - International Journal of Engineering. 16(2): 117-123.

Jimoh, A.A., Rahmon, R.O. and Joseph, S.G. (2017). Evaluation of Compressive Strength Characteristics of Structural-sized Apa (Afzelia bipindensis) and Opon (Lannea schimperi) Timber species columns found in Nigeria, Journal of Applied Science and Environmental Management (JASEM), 21(7): 1281-1285.

Jimoh, A.A., Rahmon, R.O., Babatunde, O.Y. and Tazou, O.L. (2017): Characterization and Classification of Ayunre (Albizia zygia) Timber Specie grown in Kwara State Nigeria in accordance to BS 5268 and NCP 2, Epistemics in Science, Engineering and Technology (ESET), 7(1): 549-557.

Kaura, J., Abubakar, L., Aliyu, I., and Hassan, U. 2015. EN 338 Strength grade and uncertainty models of material properties for Nigerian Grown Terminalia superba (White Afara) timber specie. Nigerian Journal of Technology (NIJOTECH), 34(1): 21-27

Mohammed, J. (2014). Reliability based analysis and calibration of Eurocode 5 Design criteria for solid timber portal frame, Unpublished PhD Thesis, submitted to the Department of Civil Engineering, Faculty of Engineering, Ahmadu Bello University, Zaria, Nigeria.

Nabade, A. M. (2012). Development of Strength Classes for Itako (Strombosia pustulata), Oporoporo (Macrocarpa bequaertii), Opepe (Nauclea diderrichii) and Ijebu (Entandrophragma cyclindricum) Nigerian Timber species based on EN 338 (2009), Unpublished M.Sc Thesis submitted to the Department of Civil Engineering, Ahmadu Bello University, Zaria, Nigeria.

NCP 2 (1973). Nigerian standard code of practice; the use of timber for construction, Nigeria Standard Organisation, Federal Ministry of Industries, Lagos, Nigeria, 10-18.

Obasi, F.A. Agbo, F.U. and Oyenekwe, C.S. (2015). Environmental and Socio-Economic Effects of Timbers Harvesting in Ebonyi State, Nigeria, African Journal of Agricultural Research (Ed.). Academic Journals, 10(11): 1233-1238.

Ozelton, E.C., and Baird, J. (1981). Timber Designer's Manual, Great Britain: Granada Publishing Limited, Technical Books Division.

Rahmon, O.O., Jimoh, A.A., Babatunde, O.Y. and Tazou, O.L. (2017): Strength Characteristics and Grading of Eku (Brachystegia eurycoma) Timber grown in Kwara State, Nigeria in accordance to BS 5268, USEP: Journal of Research Information in Civil Engineering, 14(4): 1891-1905.

Rahmon, R.O. (2018). Characterization and Grading of Four Timber Species Sourced from Timber Markets in Kwara State, Nigeria for Structural Applications, Unpublished M.E.ng Thesis submitted to the Civil Engineering Department, University of Ilorin, Ilorin, Nigeria. 